\title{
Fostering Problem Solving Skills on Prospective Science Teachers: Sprint Exercise Theme
}

\author{
Wahono Widodo ${ }^{1}$, Dhita Ayu Permata Sari ${ }^{2}$, Elok Sudibyo ${ }^{3}$ \\ Natural Science Department \\ State University of Surabaya \\ Surabaya, Indonesia \\ ${ }^{1}$ wahonowidodo@unesa.ac.id, 22dhitasari@unesa.ac.id, 33eloksudibyo@unesa.ac.id
}

\begin{abstract}
Fostering problem solving-skills on prospective science teacher is a challenging task, yet problem-solving skills is needed in $21^{\text {st }}$ century live. The aim of this study is to foster problem solving skill on prospective science teacher through problem-solving tasks on sprint exercise theme. Method of this study is one group pre-test post-test design. Students were experienced with problem-solving tasks during class, organized at "Sprint Exercise" theme that integrate biomechanics and cells metabolism into human movement process. Data was gathered with rubric, and analyzed descriptively using gain score for four components of problem-solving skills. Data analyse showed that students' problem solving skills at all four skill components improved after the treatment. It concluded that problem-solving skills can be fostered by giving students tasks to solve problem on particulary theme.
\end{abstract}

Keywords-Problem-solving skills; Prospective science teacher; sprint exercise theme.

\section{INTRODUCTION}

Science is a systematic, organized, and universal knowledge that is collected by observation and experiment [1]. Science is a knowledge contains of four aspect, i.e. attitude, process, product, and aplication. Thus, learning science should be done by collecting information by observing, eperimenting, and analyzing about natural phenomena [1]. In accordance of those statement, learning science in Indonesia secondary school also tend to polish scientific attitude, including observation, state the problem and hypothesis, designing and conducting experiment, record and present the data in the table or graph, making conclusion, and report the results to answer the question.

Due to the goal of science learning, mastering subject of key subject is not enough anymore. Some skills, such as critical thinking skills and problem solving skills are needed. Scientific process skills are not only used to understand the content, but also to apply knowledge in other situation in life for solving the problem. Thus, problem solving skills become important for prospective science teachers. The way to teach problem solving skills to prospective science teacher is by involving students in problem solving tasks. Problem-solving skills consists of four skills: (1) understanding the prolbem, (2) planning the completion, (3) implementing problem solving based on the plan, and (4) re-checking [3]. Those skills can be achieved by students if teacher prepare some problem-based activity in class.

On the other hand, science teacher in secondary school teach science by integrating science content with other theme that related to student daily life, such as sport, health, or economic problems. Science teacher should give an example through the lesson that science can be applied in everyday life, so that the lesson will be meaningfull for student. In addition to that reason, it is believed that learning something more profound in broad scope will increase understanding of some knowledge [2].

Therefore, prospective science teacher should learn how to integrate science knowledge into other theme. Integrating science to everyday life must be taught to them by giving them some experiences to integrate their science knowledge into the problem. One of a course that integrate science to everyday life in Science Department of Universitas Negeri Surabaya is "The Moving and Its Changes". This course talks about kinematics, biomechanis, and metabolism as one core subject.

Before the research, the course separated three topics into three different sessions during one semester. Students understood and mastered the context in some good level. However, they had some obstacles to integrate the subject into other subject clearly. For this reason, a study is being conduct to find a best way to teach them how to integrate their knowledge into other subject that related to every day life. Students were fostered to solve problems by integrating problems on certain theme, i.e. "Sprint Exercise".

This study aims to develop a worksheet that students (prospective teachers) can solve the problem on "Sprin Exercise." The theme help students integrate the science content into particularly theme. This worksheet also give students- prospective science teachers- a problem-solving task. The students also has to work in group so that they can collaborate with other students and discuss the solution of the problem. The worksheet developed is called "Sprint Exercise Worksheet".

\section{METHOD}

This research was pre-experimental with one group pre-test and post-test design as follows

$$
\mathrm{O} 1 \longrightarrow \mathrm{X} \longrightarrow \mathrm{O} 2
$$


Information:

O1 : score of pre-test (before treatment)

$\mathrm{O} 2$ : score of post-test (after treatment)

$\mathrm{X}$ : treatment of problem-solving tasks "Sprint Exercise" theme.

Eighteen (18) prospective science teachers became subjects for this research. They programmed the lesson during one semester in a class. They collaborated to solved the problem presented at "Sprint Exercise Worksheet" worksheet. The worksheet was judged "valid" and "very valid" categories to improve students' ability to integrate science knowledge based on their daily life by experts [4].

Before and after the test, subjects were tested using test instrument. The test assess the problem-solving skills achieved by students, including (1) understanding the problem, (2) planning the completion, (3) implementing problem solving based on the plan, and (4) reflection. The formulation for analyzing prospective science teachers achivements is as follows.

$$
\text { Percentage of problem solving }=\frac{\operatorname{Pr} e-\text { serviceteacher's score }}{\text { total score }} \times 100 \%
$$

The achievement percentage will be interpreted into criteria to determine the feasibility of student worksheet developed. The criteria for problem-solving achievement for pre-test and post-test are as follows at Table I.

The increased/decreased of problem solving skills will be analyzed by a Hake's formula as follows[5].

$$
<g>=\frac{\left(\%<S_{f}>-\%<S_{i}>\right.}{\left(100-\%<S_{i}>\right.}
$$

Information:

$\langle g\rangle$ : normalizes gain score

$S_{f} \quad$ : post-test score

$S_{i} \quad$ : pre-test score

TABLE I. SCORE CRITERIA OF PROBLEM-SOLVING SKILLS

\begin{tabular}{|c|c|c|}
\hline Score & Criteria & Description \\
\hline $0-20$ & $\begin{array}{c}\text { Very low } \\
\text { ability }\end{array}$ & The student cannot solve problem \\
\hline $21-40$ & Low ability & $\begin{array}{c}\text { The student know how to state problems, yet } \\
\text { the student cannot solve the problem. }\end{array}$ \\
\hline $41-60$ & $\begin{array}{c}\text { Average } \\
\text { ability }\end{array}$ & $\begin{array}{c}\text { The student has an average ability to solve } \\
\text { the problem. }\end{array}$ \\
\hline $61-80$ & $\begin{array}{c}\text { High ability } \\
\text { Student can solve the problem, yet the } \\
\text { student need some improvement in some } \\
\text { problem-solving skills. }\end{array}$ \\
\hline $81-100$ & $\begin{array}{c}\text { Very high } \\
\text { ability }\end{array}$ & $\begin{array}{c}\text { The student has a very high ability to solve } \\
\text { the problem. }\end{array}$ \\
\hline
\end{tabular}

The criteria of score interpretation of problem-solving skills achievement are shown as follows.
TABLE II. SCORE CRITERIA OF PRoblem-Solving SkILLS ACHIEVEMENT

\begin{tabular}{|c|c|}
\hline Percentage (\%) & Criteria \\
\hline$(<\mathrm{g}>)>0,7$ & High \\
\hline $0,7>(<\mathrm{g}>)>0,3$ & Average \\
\hline$(<\mathrm{g}>)<0,3$ & Low \\
\hline
\end{tabular}

\section{RESULTS AND DISCUSSION}

Before the treatment, students, which is prospective science teachers, did some pre-test to collect the data. The pre-test consists of some problem-solving skills question that must be answered by them clearly. All student could not pass the minimum score for this pre-test. The pre-test results showed that students must learn more about problem-solving skills through problem solving tasks.

During the lesson, the worksheet of "Sprint Exercise" students were given to students. This worksheet was asked students to play a role as a research team for a sport group. Students worked in small group of four or five. Students tried to find out weakness and strength of some sprint athletes. They discussed it in group to find a best solution to answer that question. After that, they talked to their lecturer to get some feedbacks.

The way to explore weakness and strength is by collecting data when the athletes run in a track for some certain distances. Then, students draw the result in graph. Drawing a graph is one of the goals of the lesson too. Then, they analyzed the graph to find the strength and weakness.

The results for testing the performance of each indicator can be noted in Table II. The table shows that all the problemsolving skills are in low level. After treatment, it shows students increace their ability for those skills. The mean of understanding problem skills acieved by the students was 80 . The gain score for this skills are high criteria. It means that students understand how to state the problem. The other skills that reached high criteria too is implementing problem-solving skills based on the plan. Student implemented all their plans that they decided together in group to find the strength and weakness of the athletes.

TABLE III. THE RESULTS OF PRE-TEST AND POST-TEST FOR EACH INDICATORS OF PROBLEM-SOLVING SKILLS

\begin{tabular}{|l|c|c|c|c|}
\hline \multicolumn{1}{|c|}{$\begin{array}{c}\text { Indicator of } \\
\text { Problem-Solving } \\
\text { Skills }\end{array}$} & $\begin{array}{c}\text { Pre- } \\
\text { test }\end{array}$ & $\begin{array}{c}\text { Post- } \\
\text { test }\end{array}$ & $\begin{array}{c}\text { Gain } \\
\text { Score }\end{array}$ & Criteria \\
\hline $\begin{array}{l}\text { Understanding the } \\
\text { problem }\end{array}$ & 25,83 & 80,00 & 0,73 & High \\
\hline $\begin{array}{l}\text { Planning the } \\
\text { completion }\end{array}$ & 26,11 & 75,56 & 0,67 & Average \\
\hline $\begin{array}{l}\text { Implementing problem } \\
\text { solving based on the } \\
\text { plan }\end{array}$ & 25,28 & 80,83 & 0,74 & High \\
\hline Re-checking & 20,28 & 74,44 & 0,68 & Average \\
\hline
\end{tabular}

In contrast, two other skills only got Average criteria. Those skilss are planning the completion and re-checking. Both 
criteria seems a bit hard for students to achieve. They need to search some information first before their start to make a plan. However, during the lesson students learned how to make a plan for finding a solution. Another skills is re-checking. Although this skills is only in the average criteria, students learned a lot to make conclusion from their data analyse.

TABLE IV. THE RESULTS OF PRE-TEST AND POST-TEST FOR EACH INDICATORS OF PROBLEM-SOLVING SKILLS

\begin{tabular}{|c|c|c|c|c|}
\hline No. & Pretest & Posstest & Gain Score & Criteria \\
\hline 1 & 17 & 70 & 0,64 & Average \\
\hline 2 & 21 & 74 & 0,67 & Average \\
\hline 3 & 40 & 78 & 0,63 & Average \\
\hline 4 & 23 & 80 & 0,74 & High \\
\hline 5 & 25 & 85 & 0,80 & High \\
\hline 6 & 21 & 79 & 0,73 & High \\
\hline 7 & 17 & 82 & 0,78 & High \\
\hline 8 & 13 & 83 & 0,80 & High \\
\hline 9 & 17 & 76 & 0,71 & High \\
\hline 10 & 15 & 83 & 0,80 & High \\
\hline 11 & 45 & 89 & 0,80 & High \\
\hline 12 & 41 & 75 & 0,58 & Average \\
\hline 13 & 21 & 78 & 0,72 & High \\
\hline 14 & 14 & 76 & 0,72 & High \\
\hline 15 & 19 & 84 & 0,80 & High \\
\hline 16 & 24 & 84 & 0,79 & High \\
\hline 17 & 33 & 80 & 0,69 & Average \\
\hline 18 & 41 & 81 & 0,68 & Average \\
\hline
\end{tabular}

Re-cheking skills is not an easy task to do. Students must evaluate their selves in all aspects during the activities. It is not only checking their results, but also they need to think another option that might can solve the problem. Hence, it is important for lecturer to give a chance for students to evaluate their selves.

Table III shows that most of the students increased their problem-solving skills after the treatment. Although some of them are categorized in Average Criteria, it seems they start to understand how to solve problem.

Some students said that for the first time they were confuse with what they will do for doing the tasks. It was also difficult to find references to support their suggestion. This obstacles is not because students do not understand the content of the subject, but because they do not understand how to analyzed the results. After several time they discussed their problem with the group and lecturer, they began to understand how to analyze the graph.

In spite of those obstacle, students admitted that this learning experience made them think more about relation between their knowledge about science and their everyday life. Students starts to understand that they can apply their knowledge to other situations around them if they observe more. However, students need to practice more to improving their skills. In addition, problem-solving skills can not learn by just reading a book, but also by doing some activities that solve problem.

\section{CONCLUSION}

The conclusion of this study is that the worksheet (problem solving task at "Sprint Exercise" theme) can improve students' (preservice teachers') ability to solve problem. However, preservice teachers need more time and more experience for polishing the skills further.

\section{ACKNOWLEDGMENT}

We would like to thank the Faculty of Mathematics and Natural Science, Universitas Negeri Surabaya, who supported this research. We also thank our students and colleagues in Natural Science Department for helping us with this research.

\section{REFERENCES}

[1] A. Carin and R. Sund, Teaching Science Through Discovery 3rd Edition, New York: Merril Publishing, 1993.

[2] J. D. Bransford, A. L. Brown and R. R. Cocking, How People Learn: Barin, Mind, Experience, and School, Washington D.C.: National Academiy of Science, 2000.

[3] G. S. Selçuk, S. Çaliskan, and M. Erol, "The Effects of Problem Solving Instruction on Physics," Latin Am. J. Phys. Educ., vol. 2, no. 3, pp. 151166, 2008.

[4] W. Widodo, E. Sudibyo, and D.A.P. Sari, "Analysis of expert validation on developing integrated science worksheet to improve problem solving skills of natural science prospective teachers," J. Phys.: Conf. Ser., vo. 1006, pp. 012026, 2018.

[5] R. R. Hake, "Analyzing Change/Gain Scores," [Online]. Available: http://www.physics.indiana.edu/ sdi/AnalyzingChange-Gain.pdf. 1999. 